\title{
GERMINATION ABILITY AND BIOCHEMICAL PROPERTIES OF AJUGA CHAMAEPITYS SUBSP. CHIA VAR. CHIA AND AJUGA ORIENTALIS CULTIVATED IN CLIMATIC CONDITIONS IN LAKE DISTRICT, TURKEY
}

\author{
DÖNMEZ, Ş. ${ }^{*}-$ ÖNAL, F. \\ Department of Landscape Architecture, Faculty of Architecture, Süleyman Demirel University \\ Isparta, Turkey \\ (phone: +90-246-211-3985; fax: +90-246-211-8231) \\ *Corresponding author \\ e-mail: sirindonmez@sdu.edu.tr \\ (Received $7^{\text {th }}$ Jan 2019; accepted $20^{\text {th }}$ Feb 2019)
}

\begin{abstract}
The aim of this study is to determine the germination ability and biochemical properties of seedlings of two taxa (Ajuga chamaepitys subsp. chia var. chia, Ajuga orientalis) belonging to the Lamiaceae family which is naturally distributed in Lakes District-Turkey and cultivated in the Botanic Garden of Süleyman Demirel University in Isparta. These two taxa, which have usage potential as ornamental, medicinal and aromatic plants, were cultivated in 2015 vegetation period and seeds were collected at the end of 2016 vegetation period. During the same vegetation period, seeds were also collected from the areas where these two species were naturally grown. Seed germination tests were performed in 2017 vegetation period on the plants. Seed germination tests and seedling raising tests were carried out in the seedling and phenological properties (plant height, plant diameter, leaf width, leaf length) and SPAD values were also measured. Some macro and micro elements (Total N, P, K, Ca, Mg, $\mathrm{Fe}, \mathrm{Cu}, \mathrm{Mn}$ and $\mathrm{Zn}$ ) and volatile oil compounds were analysed in the samples taken. As a result of the study, germination was not observed in Ajuga chamaepitys subsp. chia var. chia; however, seedling raising rate was between $33 \%$ and $40 \%$. Seedling raising speed was $33.7 \%$ in the trial area and $36.41 \%$ in the seeds collected from the natural habitat. The germination rate of Ajuga orientalis was found to be $18 \%$ in the seeds taken from the natural habitat and $21.33 \%$ in the seeds taken from cultivars. Seedling raising rate was $43.33 \%$ in the seeds taken from the natural habitat and $60 \%$ in the seeds obtained from the trial area. Although the germination ability of the seeds from both origins (natural habitat and cultivars) were low, the phenological properties measurements and the biochemical analysis results were in a close relation with each samples.
\end{abstract}

Keywords: Lamiaceae, Ajuga sp., cultivated plant, seed, volatile components

\section{Introduction}

Today, the basic material of all designs is nature itself. In the creation and development of design, the use of various structural and plant materials inspired by nature is an indispensable approach. The selection of naturally propagated species from the area or region in which the design will be put, is an important factor both for sustainable design and for lowering costs such as irrigation and maintenance (Bassuk, 2017). In the world, especially in urban areas where water scarcity is felt more prominently in recent years, alternatives to wide grass surfaces are sought, and more sensitive to nature and less water consuming designs come to the fore. In order to put into practice these designs, studies were carried out on the cultivated and development of the natural species belonging to these regions (Çakır and Dönmez, 2018; Gül et al., 2012). However, in order to use natural species in planted design studies, it is necessary to know the breeding and production properties of plant materials. Although successful 
results can be obtained in some cases in terms of visual characteristics in the cultivation studies, the genetic continuity of the plants can not be achieved and successful results can not be obtained. The most remarkable and critical stages during the life cycle of plants are seed germination and seedling establishment (Copete et al., 2015). Besides, it is necessary to know the germination time and their growth properties in order to be produced both as industrial usage and as ornamental plant.

Lamiaceae family is represented by 400 genera and 3200 species in the world (Kahraman et al., 2009; Bazarragchaa et al., 2012). Members of these families are concentrated mainly in the Mediterranean countries, Australia, South West Asia and South America. Almost in all habitat types and at all heights, Lamiaceae family members can grow and there are very few regions in which they can not be seen. Lamiaceae family in Turkey is one of the important gene centers. About 546 species are represented in 45 genus. The rate of endemism in Turkey is approximately $44.5 \%$. Most of the members of the Lamiaceae family are rich in ornamental leaves, flowers, angular bodies and volatile oil; for this reason, they are very important in landscape architecture, pharmacy, food and cosmetic industries (Castro et al., 2011; Kahraman et al., 2009; Guo et al., 2011). It is known by previous studies that the volatile oil of Ajuga species have antibacterial properties thus it can be used as medicinal and aromatic plant (Turkoğlu et al., 2010; Yaldiz, 2012; Delezar et al., 2012; Göder et al., 2015).

"Ajuga chamaepitys subsp. chia var. chia" also known as Ground Pine can be occured in Greece, Crimea, Palestine, North West and West Iran, Northern Iraq. In Turkey; it can be seen in almost all regions, up to $2000 \mathrm{~m}$ above sea level (Davis, 1982; Coll and Tandron, 2008). This taxa, which can be sized up to $30 \mathrm{~cm}$ in diameter and 10 $\mathrm{cm}$ in length, is yellow in color and can be flowered during the vegetation period (Fig. 1). This suffrutescent plant can be used either as ground covering or as an element of emphasis (Israili and Lyoussi, 2009; Dönmez et al., 2017; Jakovljević et al., 2015).

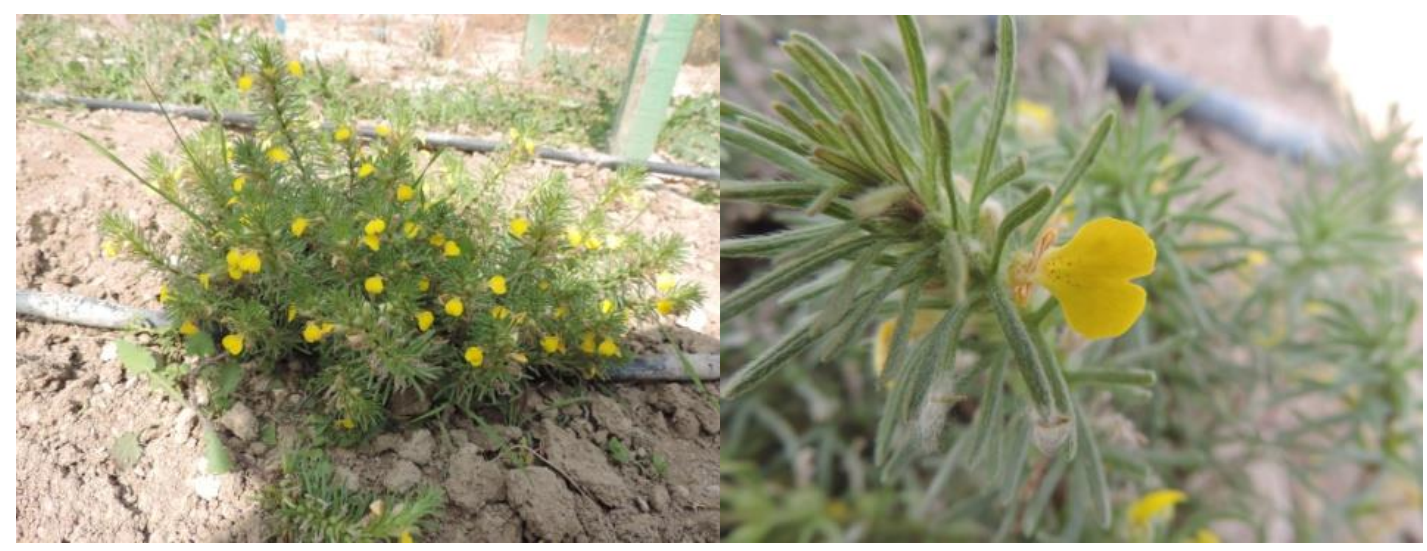

Figure 1. Ajuga chamaepitys subsp. chia var. chia

"Ajuga orientalis" can be grown in Crimea, Sicily, West Syria, Cyprus, Caucasus and North West Iran. In Turkey, it is seen in Mediterranean, Aegean, Black Sea and Central Anatolia regions up to $2500 \mathrm{~m}$ above sea level (Davis, 1982). It is a suffrutescent perennial herbaceous plant that can be grown up to $40 \mathrm{~cm}$ (Dönmez et al., 2017). The flowers are violet-blue and cream-colored. Ajuga orientalis stands out with its dense green texture (Fig. 2). It is suitable for use as a background in plant design. It is thought that its use in waterfronts and humid areas will increase the visual appeal. 


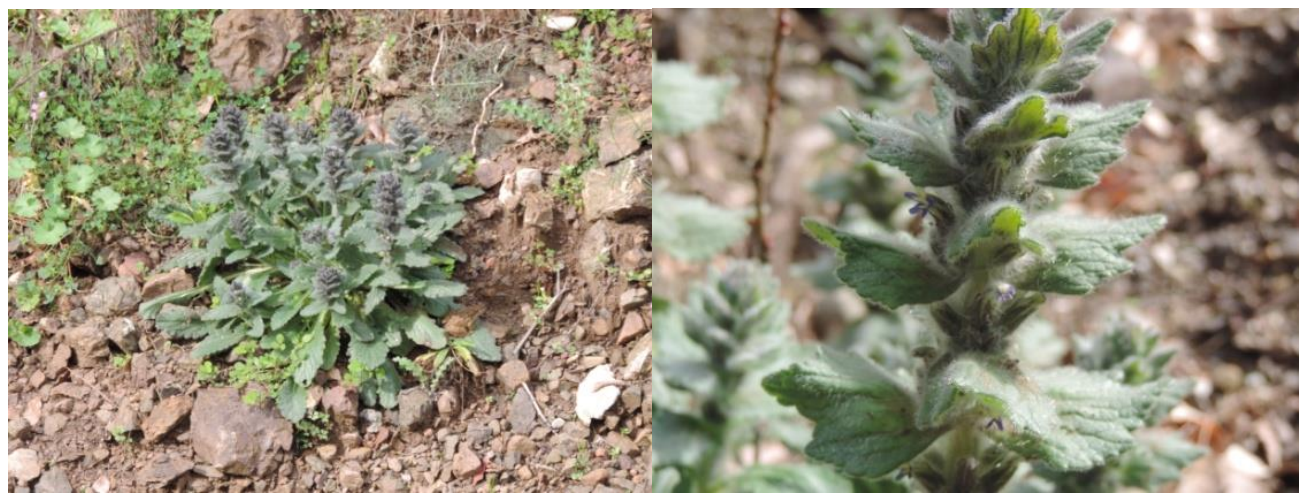

Figure 2. Ajuga orientalis

These taxas were cultivated for the first time (Dönmez et al., 2018). To the best our knowledge, there are no papers on the germination and seedling growth of these taxas. From this point of view, the aim of the study was to determine the germination abilitiy of Ajuga chamaepitys subsp. chia var. chia and Ajuga orientalis taxa belonging to Lamiaceae family, which is naturally grown in Lakes District, Turkey and cultivated in Isparta Süleyman Demirel University (SDU) Botanic Garden.

\section{Materials and methods}

The plants were cultivated in "SDU Botanic Garden" during the 2015 vegetation period. Ajuga chamaepitys subsp. chia var. chia's natural habitat plant samples were collected from Asağıökdere, Isparta (GÜL HERBARIUM No: 14340). Ajuga orientalis plants were collected from Kemer, Antalya (GÜL HERBARIUM No: 14341). In May 2015, trial parcels were created in SDU Botanic Garden. A total of 6 parcels were established, three of which with replicates, and each parcel consisting of 25 plants. As the physiographic and climatic factors were considered the same in the trial area where the experimental areas were established, the parceling was done in accordance with the Randomized Complete Block Design. Irrigation and drip was made by irrigation system. It was observed that 55 and 40 plants adapted in trial area, respectively, for Ajuga chamaepitys subsp. chia var. chia and Ajuga orientalis. At the end of 2016 (July) vegetation period, seeds were collected from natural habitat and trial area plants. Seeds were stored at $4{ }^{\circ} \mathrm{C}$ until germination experiments. Germination experiments were carried out after nine months. At the start of the 2017 (April) vegetation period, they were sowed, measurements and analyzes were carried out on the seedlings.

\section{Germination and seedling raising test}

The germination test was carried out in petri dishes $(9 \mathrm{~cm}$ in diameter) with 3 replicates and 50 seeds were put into each dishes (Fig. 3). Sufficient amount (about $5 \mathrm{ml}$ ) of pure water was added and seeds were allowed to germinate at $25{ }^{\circ} \mathrm{C}$ in the dark. $1 \mathrm{~mm}$ length of rootlet is decided to be adequate for germination and germinated seeds were counted every day. This process was continued until the number of germinated seeds is fixed. Germination rate $(\mathrm{GR}, \%)$ was calculated as percentage of the 
ratio of germinated seeds to total sown seeds. Average Germination Speed (AGS, day) were calculated according to Equation 1 (Pedersen et al., 1993).

$$
A G S=\left(A_{1} \cdot D_{1}+A_{2} \cdot D_{2}+\ldots \ldots . . A_{n} \cdot D_{n}\right) /\left(A_{1}+A_{2}+\ldots \ldots . . A_{n}\right)
$$

A: The number of seeds germinated every day,

$D:$ The day required for germination of the seed,

$\mathrm{n}$ : Number of the days until the last count.

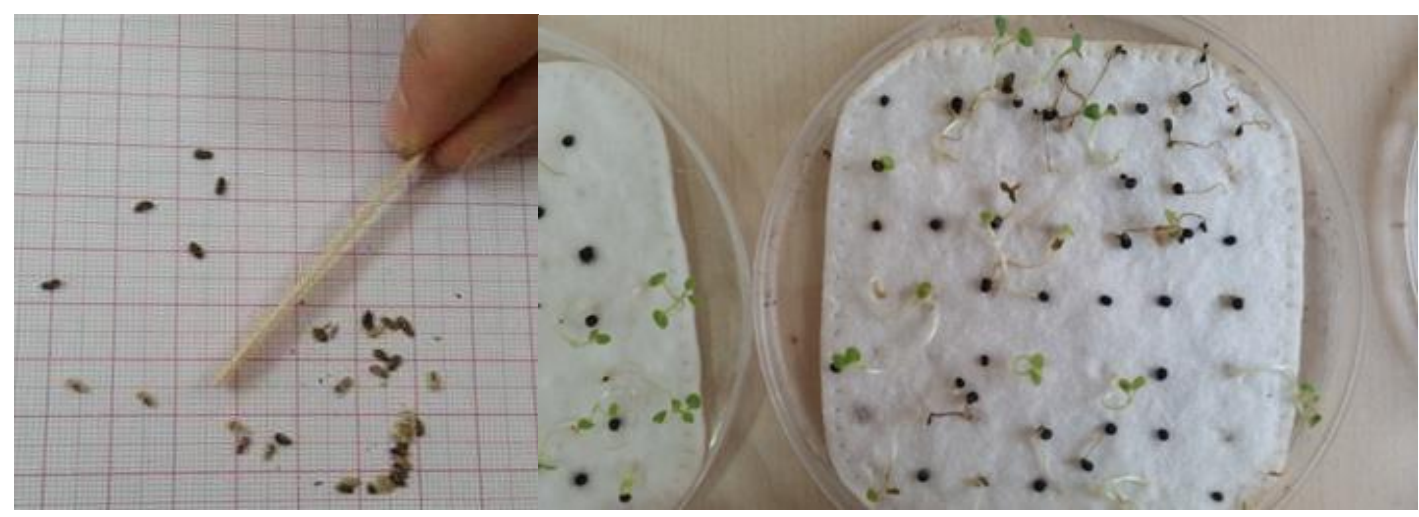

Figure 3. A view from germination test

Seeds obtained from the natural habitat and trial area were planted in a viol $(4 \mathrm{~cm} \times 4 \mathrm{~cm} \times 6 \mathrm{~cm})$ which includes peat soil and perlite and placed in greenhouse. In 3 replicated experiments, 30 seeds were planted in each replicate for the seedling tests. Appearance of cotyledon leaves was considered as seedling (Fig. 4). Each day the seedling was recorded and this process was continued until the number of seedlings was fixed. Seedling raising rate (SRR, \%) was calculated as percentage of the ratio of seedlings to total sown seeds. Average Seedling Raising Speed (days, ASRS) were calculated according to Equation 2.

$$
\operatorname{ASRS}=\left(\mathrm{A}_{1} \cdot \mathrm{D}_{1}+\mathrm{A}_{2} \cdot \mathrm{D}_{2}+\ldots \ldots . \mathrm{A}_{\mathrm{n}} \cdot \mathrm{D}_{\mathrm{n}}\right) /\left(\mathrm{A}_{1}+\mathrm{A}_{2}+\ldots \ldots \mathrm{A}_{\mathrm{n}}\right)
$$

A: The number of seeds raising every day,

D: The day required for germination,

$\mathrm{n}$ : Number of the days until the last count.

\section{Determination of phenological properties and chlorophyll (SPAD) value}

After germinating, seedlings reached a certain size (65 days after seed sowing), 10 of them were selected and transferred to viols. Flowering was not seen in seedlings. 2017 vegetation period phenological properties such as plant height, plant diameter, leaf width and leaf length were measured. SPAD value of the plants was also determined on the plants (Fig. 4). SPAD-502 (Minolta Ltd, Osaka Japan) is hand-held chlorophyll meter equipment based on the measurement of leaf chlorophyll content. It measures the leaf transmittance in red light at $650 \mathrm{~nm}$ (at which chlorophyll absorbs) and in nearinfrared light at $940 \mathrm{~nm}$ (for the correction of leaf thickness). The ratio of these two transmission values is referred to as SPAD reading or SPAD value (Monostori, 2016). 
SPSS (Statistical Programs for Social Science) 13.0 program was used for statistical analyses. The mean values and standard deviation values of the data were given.

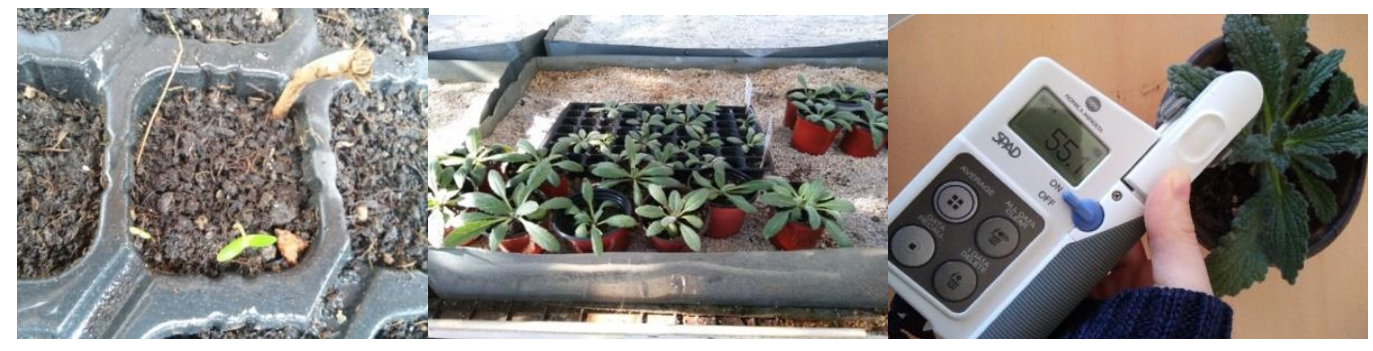

Figure 4. Seedlings on the experimental plots and determination of chlorophyll value

\section{Biochemical analysis}

It is important to ensure the continuity of their biochemical properties as well as their phenological properties especially in medicinal aromatic plants. Biochemical analyzes were performed in the seedlings in 2017 vegetation period and their average values were given. Randomly selected five plants from each plot were cut from the base at each stage and separated into leaf+stem and head. They were oven dried at $65^{\circ} \mathrm{C}$ until constant weight was obtained. The oven dried weight of leaf, stem and head were recorded. Total $\mathrm{N}$ determination was made according to the Regular Kjeldahl Method (Boț et al., 2017) and Phosphorus (P) amount was determined by Vanadomolybdophosphoric Yellow Color Method (Spectrophotometric) (Rajkumar et al., 2017). Determination of Potassium (K), Calcium (Ca), Magnesium (Mg), Iron (Fe), Copper $(\mathrm{Cu})$, Manganese $(\mathrm{Mn})$ and Zinc $(\mathrm{Zn})$ were determined by wet decompositionAAS (Atomic Absorption Spectroscopy) method (Tariq et al., 2017).

Besides, after the plant materials collected, flower and leaf samples were subjected to solid phase microextraction (SPME) by GC-MS system. $2 \mathrm{~g}$ of samples were placed into a $10 \mathrm{ml}$ vial. After incubation for $30 \mathrm{~min}$ at $60{ }^{\circ} \mathrm{C}$, SPME fibre was pushed through the headspace of a sample vial to absorb the volatiles and then inserted directly into the injection port of the GC-MS (Shimadzu 2010 Plus GC-MS with the capillary column, Restek Rxi ${ }^{\circledR}-5$ Sil MS $\left.30 \mathrm{~m} \times 0.25 \mathrm{~mm}, 0.25 \mu \mathrm{m}\right)$ at a temperature of $250{ }^{\circ} \mathrm{C}$ for desorption ( $5 \mathrm{~min}$ ) of the adsorbed volatile compounds. The constituents were identified using retention times of standard substances by aligning mass spectra with the data given in the Wiley, NIST Tutor, FFNSC library (Özderin et al., 2016).

\section{Results and discussions}

\section{Germination ability and seedling raising rate of plant}

Seed dormancy varies depending on the temperature and species among Lamiaceae family (Copete et al., 2015). Although there is no study in these taxas, the different species belonging to the Lamiaceae family are mentioned as non-dormant (Panuccio et al., 2017). In germination experiments, no germination was observed in Ajuga chamaepitys subsp. chia var. chia plants. The germination rate of Ajuga orientalis was $18 \%$ in the seeds taken from the natural habitat and $21.33 \%$ in the seeds taken from the trial area. Although there was no germination for Ajuga chamaepitys subsp. chia var. chia in petri dishes, it was determined that seedlings emerged in peat soil experiments. 
Seedling rising rate increased in seedling trials for both taxa (Table 1). In germination experiments in soil, herbal seeds have adaptation advantages, since seeds are protected from environmet (Adams et al., 2005). Avarage seedling raising speed for Ajuga chamaepitys subsp. chia var. chia was 23.67 days. It was observed that germination was seen between the days of 20-30. Avarage seedling raising speed for Ajuga orientalis was 20.67 days and germination of these seeds was mostly seen between the days of 20-35 (Fig. 5). In different species of the Lamiaceae family, the percentage of germination varies from 20 to $50 \%$, while the average germination time can be as long as 30 days (Mattana et al., 2016).

Table 1. Germination and seedling raising data of plant

\begin{tabular}{|c|c|c|c|c|c|c|c|c|c|}
\hline \multicolumn{2}{|l|}{ Plant } & $\begin{array}{l}\text { GR } \\
(\%)\end{array}$ & sig. & $\begin{array}{l}\text { AGS } \\
\text { (day) }\end{array}$ & sig. & $\begin{array}{l}\text { SRR } \\
(\%)\end{array}$ & sig. & $\begin{array}{c}\text { ASRS } \\
\text { (day) }\end{array}$ & sig. \\
\hline \multirow{2}{*}{$\begin{array}{l}\text { A. chamaepitys subsp. } \\
\text { chia var. chia }\end{array}$} & Trial & - & \multirow[b]{2}{*}{-} & - & & 33.06 & \multirow{2}{*}{$0.02^{\mathrm{ns}}$} & 36.43 & \multirow{2}{*}{$0.09^{\text {ns }}$} \\
\hline & Natural & - & & - & & 40.30 & & 33.43 & \\
\hline \multirow{2}{*}{ A. orientalis } & Trial & 18.00 & \multirow{2}{*}{$0.10^{\text {ns }}$} & 20.68 & \multirow{2}{*}{$0.99^{\text {ns }}$} & 43.44 & \multirow{2}{*}{$0.06^{\mathrm{ns}}$} & 22.38 & \multirow{2}{*}{$0.51^{\mathrm{ns}}$} \\
\hline & Natural & 21.36 & & 20.67 & & 48.28 & & 23.57 & \\
\hline
\end{tabular}

${ }^{n s}$ Not statistically significant (independent sample t test)
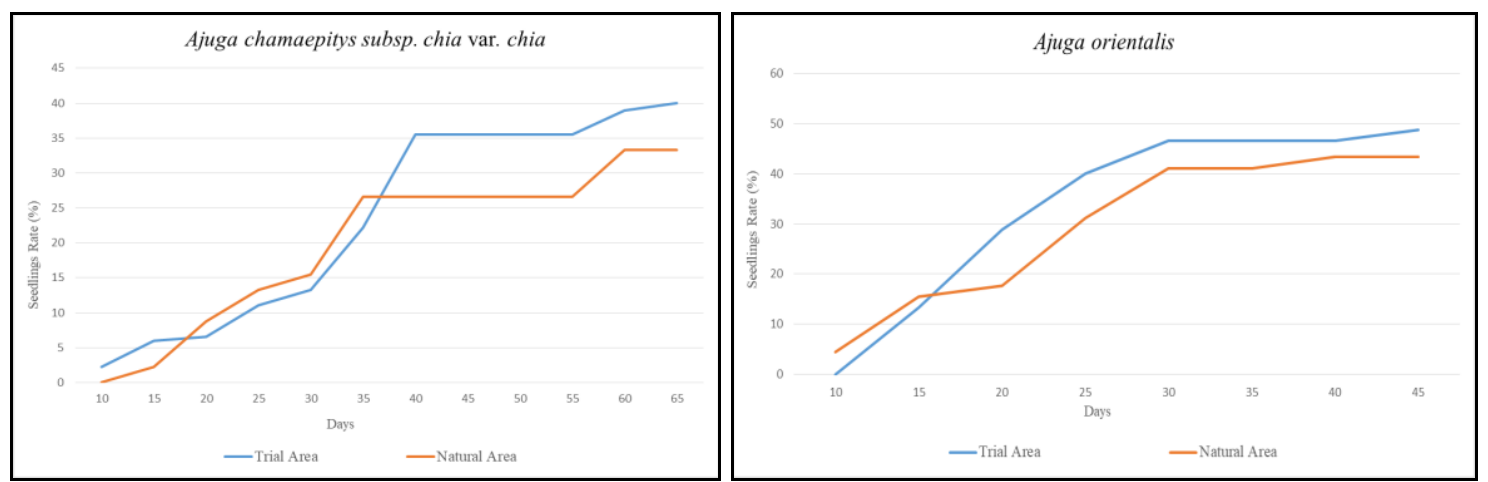

Figure 5. Distribution of seedling rate by day

\section{Phenological properties and chlorophyll (SPAD value)}

These Ajuga taxas are horizantally growing plants and height and diameter values are directly related to each other (Dönmez et al., 2017). According to the data in Table 2, no change was observed in plant height and diameter values in the seedlings obtained from seeds taken from natural habitat and trial area.

Chlorophyll is a necessery pigment for photosynthesis. The content of chlorophyll is one of main sources reflecting leaf photosynthesis ability and plant health condition (Jiang et al., 2017). The connection between leaf chlorophyll content determined in vitro and SPAD meter readings (SPAD values) were extensively analysed and usually parameterised by linear relationship (Monostori, 2016). Chlorophyll was measured almost 50.00 SPAD value in both plant species. This rate corresponds to the rate in which the seeds are collected from rootstock plants (Dönmez, 2018). When the phenological properties were compared, no statistically significant difference was found between the seeds collected from natural habitat and trial area. Although studies on 
phenological properties of Ajuga seedlings is out of our knowledge, results are compatible with some of the species belonging to Lamiaceae family (Rather et al., 2016; Mandal et al., 2008).

Table 2. Comparison of phenological properties of plants

\begin{tabular}{c|c|c|c|c|c}
\hline \multirow{2}{*}{ Measurements } & \multirow{2}{*}{ Group } & \multicolumn{2}{c|}{$\begin{array}{c}\text { A. chamaepitys } \\
\text { subsp. chia var. chia. }\end{array}$} & \multicolumn{2}{c}{ A. orientalis } \\
\cline { 3 - 6 } & & Average & sig. & Average & sig. \\
\cline { 3 - 6 } & Trial & $10.90 \pm 0.9$ & $0.79^{\mathrm{ns}}$ & $20.25 \pm 1.5$ & $0.37^{\mathrm{ns}}$ \\
\multirow{2}{*}{ Length (cm) } & Natural & $11.00 \pm 0.8$ & & $20.95 \pm 1.8$ & \\
\hline \multirow{2}{*}{ Height (cm) } & Trial & $4.40 \pm 0.6$ & $0.33^{\mathrm{ns}}$ & $2.95 \pm 0.7$ & $0.88^{\mathrm{ns}}$ \\
& Natural & $4.10 \pm 0.6$ & & $2.90 \pm 0.7$ & \\
\hline \multirow{2}{*}{ Leaf width (cm) } & Trial & $2.21 \pm 0.5$ & $0.36^{\mathrm{ns}}$ & $2.43 \pm 0.3$ & $0.22^{\mathrm{ns}}$ \\
& Natural & $2.45 \pm 0.5$ & & $2.68 \pm 0.4$ & \\
\hline \multirow{2}{*}{ Leaf length (cm) } & Trial & $4.25 \pm 0.5$ & $0.43^{\mathrm{ns}}$ & $5.45 \pm 0.5$ & $0.46^{\mathrm{ns}}$ \\
& Natural & $4.05 \pm 0.6$ & & $5.29 \pm 0.4$ & \\
\hline \multirow{2}{*}{ Chlorophyll (SPAD value) } & Trial & $52.00 \pm 3.2$ & $0.77^{\mathrm{ns}}$ & $50.26 \pm 1.2$ & $0.45^{\mathrm{ns}}$ \\
& Natural & $51.57 \pm 3.3$ & & $49.83 \pm 1.2$ & \\
\hline
\end{tabular}

${ }^{\mathrm{n}}$ Not statistically significant (independent sample $\mathrm{t}$ test)

\section{Biochemical properties}

As a result of biochemical analyzes, the nitrogen amount of Ajuga chamaepitys subsp. chia var. chia was found to be $2.15 \%$ in the seedlings obtained from natural habitat seeds and $2.23 \%$ from trial area seeds. There were seen little differences between the other macro and micro-element analyzes, the seedlings of the seeds obtained from the trial area have higher calcium, copper and manganese ratios (Table 3). The nitrogen amount of Ajuga orientalis was $2.94 \%$ in the seedlings obtained from the natural habitat seeds and $3.42 \%$ in the seedlings obtained from trial area seeds. In the other macro and micro-element analyzes, the phosphorus, potassium and copper ratios of the seedlings obtained from the trial area seeds were found to be higher. In the literature, there is no study on the macro and micro element content of these plants.

48 different volatile components of $A$. chamaepitys subsp. chia var. chia, collected from both area, were determined by GC-MS after solid phase micro extraction (SPME). Limonene, which is the highest component, was determined as $28.17 \%$ in the natural plants seedlings and $29.24 \%$ in the cultivated plant seedlings. The second highest component, $\beta$-pinene was found to be $17.71 \%$ in the natural plants seedlings and $18.26 \%$ in the cultivated plant seedlings (Table 4). These results coincide with the studies done by Azizan et al. (2002) and Delezar et al. (2012). In addition, the same components were also seen to be the highest in rootstocks where seeds were collected (Dönmez, 2018). In A. orientalis seedligs volatile oil, 41 components were identified from both area samples. 1-Octen-3-ol, which is the highest component, was determined as $23.48 \%$ in the natural plants seedlings and $22.89 \%$ in the cultivated plant seedlings (Table 5). However, germacrene-D and $\beta$-cubebene, was previously identified as the highest compounds in this plant (Saijadi and Ghannadi, 2004; Yaldiz, 2012). 
Table 3. Volatile compounds of A. chamaepitys subsp. chia var. chia seedlings

\begin{tabular}{c|c|c|c|c}
\hline \multirow{2}{*}{ Analysis } & \multicolumn{2}{|c}{ A. chamaepitys subsp. chia var. chia } & \multicolumn{2}{c}{ A. orientalis } \\
\cline { 2 - 5 } & Natural areas & Trial areas & Natural areas & Trial areas \\
\hline Nitrogen (N) (\%) & 2.15 & 2.23 & 2.94 & 3.42 \\
Phosphorus (P) (\%) & 0.14 & 0.12 & 0.25 & 0.26 \\
Potassium (K)(\%) & 2.41 & 2.36 & 4.04 & 4.12 \\
Calcium (Ca)(\%) & 1.64 & 1.73 & 2.08 & 1.93 \\
Magnesium (Mg)(\%) & 0.94 & 0.92 & 0.95 & 0.86 \\
Iron (Fe)(ppm) & 131.02 & 128.31 & 154.81 & 152.61 \\
Copper (Cu) (ppm) & 21.64 & 22.01 & 18.90 & 19.31 \\
Manganese (Mn)(ppm) & 26.14 & 27.20 & 42.86 & 40.23 \\
Zinc (Zn) (ppm) & 62.14 & 61.79 & 101.89 & 98.42 \\
\hline
\end{tabular}

Table 4. Volatile compounds of A. chamaepitys subsp. chia var. chia seedlings

\begin{tabular}{|c|c|c|}
\hline Components (\%) & Natural areas & Trial areas \\
\hline Ethanol & 0.33 & 0.45 \\
\hline Me-acetate & 0.35 & 0.25 \\
\hline 2,2-dimethyl-4-ethylhexane & 0.36 & 0.39 \\
\hline Cyclopentanol & 0.16 & 0.13 \\
\hline 2-penten-1-ol & 0.10 & 0.12 \\
\hline n-hexanal & 0.22 & 0.27 \\
\hline 2-hexanal & 0.52 & 0.51 \\
\hline 3-hexen-1-ol & 0.07 & 0.08 \\
\hline 2-hexen-1-ol & 0.15 & 0.18 \\
\hline n-hexanol & 0.09 & 0.08 \\
\hline Heptanal & 0.09 & 0.08 \\
\hline$\alpha$-thujene & 0.18 & 0.16 \\
\hline$\alpha$-pinene & 1.92 & 1.85 \\
\hline Benzaldehyde & 0.09 & 0.07 \\
\hline Sabinene & 0.25 & 0.22 \\
\hline$\beta$-pinene & 17.71 & 18.26 \\
\hline 1-octen-3-ol & 2.09 & 2.16 \\
\hline$\beta$-myrcene & 2.62 & 2.58 \\
\hline Cymol & 2.23 & 2.10 \\
\hline Limonene & 28.17 & 29.24 \\
\hline Eucalyptol & 0.46 & 0.33 \\
\hline$\beta$-ocimene & 0.10 & 0.08 \\
\hline 1,4-cyclohexadiene & 0.51 & 0.44 \\
\hline Linalool & 1.33 & 1.28 \\
\hline Trans-limonene oxide & 0.44 & 0.42 \\
\hline 4-terpineol & 0.19 & 0.23 \\
\hline$\alpha$-terpineol & 0.21 & 0.22 \\
\hline p-allylanisole & 0.32 & 0.30 \\
\hline Linalyl acetate & 0.85 & 0.95 \\
\hline$\alpha$-cubebene & 0.71 & 0.76 \\
\hline Cyclosativene & 0.21 & 0.27 \\
\hline Copaene & 3.18 & 3.39 \\
\hline$\alpha$-bulnesene & 0.36 & 0.12 \\
\hline$\beta$-bourbonene & 0.26 & 0.20 \\
\hline$\beta$-cubebene & 2.98 & 2.87 \\
\hline
\end{tabular}


1-cyclopropazulene

3,5-dimethylcyclohex-1-ene-4carboxyaldehyde

Caryophyllene

Germacrene-D

Epibicyclosesquiphellandrene

$\Gamma$-cadinene

$\beta$-ionone

Viridiflorene

Cyclohexane

$\alpha$-muurolene

$\Delta$-cadinene

Torreyol

Viridiflorol

0.48
1.62
2.71
12.60
0.21
3.81
0.40
1.20
0.28
0.98
1.30
0.15
0.28

0.33

4.99

0.44

1.35

0.24

0.82

1.15

0.21

0.24

Table 5. Volatile compounds of A. orientalis seedlings

\begin{tabular}{|c|c|c|}
\hline Components (\%) & Natural areas & Trial areas \\
\hline Acetaldehyde & 1.71 & 1.34 \\
\hline Ethanol & 1.30 & 1.69 \\
\hline 7-hydroxy-5,6,7,8-tetrahydroindoliziaine & 0.09 & 0.07 \\
\hline Me-acetate & 1.01 & 1.21 \\
\hline 2-butenal & 0.22 & 0.23 \\
\hline 2-pentanone & 0.92 & 0.89 \\
\hline 2-pentenal & 0.11 & 0.12 \\
\hline 1-pentanol & 0.10 & 0.19 \\
\hline 2-penten-1-ol & 0.22 & 0.26 \\
\hline n-hexanal & 1.11 & 1.36 \\
\hline 2-hexenal & 5.15 & 5.39 \\
\hline 3-hexenyl & 0.43 & 0.27 \\
\hline 2-hexen-1-ol & 1.12 & 1.08 \\
\hline n-hexanol & 1.41 & 1.66 \\
\hline Ocimene & 0.06 & 0.09 \\
\hline$\alpha$-pinene & 9.29 & 9.13 \\
\hline 2-heptenal & 0.11 & 0.07 \\
\hline Benzaldehyde & 0.10 & 0.06 \\
\hline Sabinene & 0.18 & 0.23 \\
\hline$\beta$-pinene & 0.98 & 1.13 \\
\hline Bicycloheptane & 1.70 & 1.91 \\
\hline 1-Octen-3-ol & 23.48 & 22.89 \\
\hline$\beta$-myrcene & 4.31 & 4.69 \\
\hline 2,4-heptadienal & 2.11 & 2.36 \\
\hline$\delta 3$-carene & 2.11 & 2.14 \\
\hline n-octan-3-ol & 1.76 & 1.79 \\
\hline Cymol & 0.98 & 0.69 \\
\hline Limonene & 13.02 & 12.84 \\
\hline 1,4-cyclohexadiene & 1.43 & 1.26 \\
\hline$\alpha$-terpinolene & 2.92 & 2.79 \\
\hline nonanal & 1.92 & 1.61 \\
\hline Linalool & 0.76 & 0.96 \\
\hline Hexyl butanoate & 0.66 & 0.83 \\
\hline Trans-Limonene oxide & 1.28 & 1.25 \\
\hline 2-octenal & 0.80 & 0.83 \\
\hline
\end{tabular}




\begin{tabular}{c|c|c} 
p-allylanisole & 0.66 & 0.73 \\
Decanal & 0.15 & 0.16 \\
Linalyl acetate & 0.93 & 0.87 \\
Anethole & 1.43 & 1.61 \\
Dodecane & 0.66 & 0.61 \\
2-butenoic acid & 3.46 & 3.22 \\
Pentanoic acid & 1.49 & 1.44 \\
Tridecane & 0.98 & 0.79 \\
Valencene & 1.96 & 1.90 \\
$\alpha$-farnesene & 3.43 & 3.38
\end{tabular}

\section{Conclusion}

It was seen that the seedling rising rate in production of Ajuga chamaepitys subsp. chia var. chia with seed was about $35 \%$ and the rising speed was found to be between 33 and 36 days. Seed experiments were carried out in seeds collected from plants randomly and no improving nursing material was given to the seeds. The phenological properties and biochemical structures of the seedlings had the same characteristics. The seedling rate in production of Ajuga orientalis with seed was about $45 \%$ and the rising speed was 23 days. There were no differences in germination and seedling characteristics of the seeds. Although germination ratio was seen to be low, the trial area seedlings had the same germination ability with natural plants.

Acknowledgements. This work is a part of a project supported by The Scientific and Technological Research Council of Turkey (TUBITAK) with the project number 1140345.

\section{REFERENCES}

[1] Bassuk, N. (2017): The Key to Sustainable Urban Landscape Establishment. - Routledge Handbook of Urban Forestry. Taylor and Francis, London, pp. 293-307.

[2] Bazarragchaa, B., Myoung, L. S., Yuon, L. H. (2012): Pollen morphology of the family Lamiaceae in Mongolia. - Journal of Korean Nature 5(2): 169-179.

[3] Boț, A. I., Păcurar, I., Szajdak, L., Roșca, S., Păcurar, H., Pleșa, V. C. (2017): Determining the amount of total nitrogen, total organic carbon and $\mathrm{C}: \mathrm{N}$ ratio for eight blueberry plantations from northwest region of development. - ProEnvironment 10: 126134.

[4] Çakır, M., Dönmez, Ş. (2018): Xeriscape: efficient water use approach in landscape architecture. - V. International Multidisciplinary Congress of Eurasia, Barcelona Spain, pp. 293-296.

[5] Castro, A., Coll, C., Afra, M. (2011): Neo-clerodane diterpenoids from Ajuga bracteosa. - Journal of Natural Products 74: 1036-1041.

[6] Coll, J., Tandron, Y. A. (2008): Neo-clerodane diterpenoids from Ajuga: structural elucidation and biological activity. - Phytochemistry Review 7: 25-49.

[7] Copete, M. A., Herranz, J. M., Ferrandis, P., Copete, E. (2015): Annual dormancy cycles in buried seeds of shrub species: germination ecology of Sideritis Serrata (Labiatae). Plant Biology 17: 798-807.

[8] Davis, P. H. (1982): Flora of Turkey and the East Aegaen Islands 7. - Edinbourgh University Press, Edinbourgh.

[9] Delazar, A., Delnavazi, M., Yassa, N., Parkhideh, S., Delazar, N., Nahar, L., Sarker, S. D. (2012): Essential oil composition and isolation of free-radical-scavenging phenolic 
glycosides from the aerial parts of Ajuga chamaepitys growing in Iran. - Brazilian Journal of Pharmacognosy 22(2): 299-305.

[10] Dönmez, Ş., Basıç, G., Fakir, H., Özçelik, H., Yazıcı, N., Kuş Şahin, C., Gül, A., Dönmez, İ. E. (2017): Visual characteristics of some species belonging to the family of Lamiaceae in the Lake District. - International Journal of Engineering Sciences \& Research Technology (6)12: 256-261.

[11] Adams, V. M., Marsh, D. M., Knox, J. S. (2005): Importance of the seed bank for population viability and population monitoring in a threatened wetland herb. - Biological Conservation 124: 425-436.

[12] Göger, F., Köse, Y. B., Göger, G., Demirci, F. (2015): Phytochemical characterization of phenolics by LC-MS/MS and biological evaluation of Ajuga orientalis from Turkey. Journal of the Bangladesh Pharmacological Society 10: 639-644.

[13] Gül, A., Özçelik, H., Uzun, Ö. F. (2012): Isparta Yöresindeki Bazı Doğal Yer örtücü Bitkilerin Adaptasyonu ve Özellikleri. - SDÜ Fen Bilimleri Enstitüsü Dergisi,16(2): 133145.

[14] Guo, P., Li, Y., Xu, J., Liu, C., Ma, Y., Guo, Y. (2011): Bioactive neo-clerodane diterpenoids from whole plants of Ajuga ciliata Bunge. - Journal of Natural Products 74: 1575-1583.

[15] Hanlon, E. A. (1998): Determination of potassium, calcium, and magnesium in plants by atomic absorption techniques. Plant analysis reference procedures for the southern region of the United States. - Southern Cooperative Services Bulletin 368: 30-34.

[16] Israili, Z. H., Lyoussi, B. (2009): Ethnopharmacology of the plants of genus Ajuga. Pakistan Journal of Pharmaceutical Sciences 22(4): 425-462.

[17] Jakovljević, D. Z., Sava, M. Vasić, S. M., Stanković, M. S., Ljiljana, R., Čomić, L. R., Topuzović, M. D. (2015): Secondary metabolite content and in vitro biological effects of Ajuga chamaepitys (L.) Schreb. subsp. chamaepitys. - Archives of Biological Sciences, Belgrade 67(4): 1195-1202.

[18] Jiang, C., Johkan, M., Hohjo, M., Tsukagoshi, S., Maruo, T. (2017): A correlation analysis on chlorophyll content and SPAD value in tomato leaves. - HortResearch 71: $37-42$.

[19] Kahraman, A., Celep, F., Doğan, M. (2009): Morphology, anatomy and palynology of Salvia indica L. (Labiatae). - World Applied Sciences Journal 6(2): 289-296.

[20] Mandal, M. S., Chakraborty, D. Gupta, K. (2008): Seed size variation: influence on germination and subsequent seedling performance in Hyptis suaveolens (Lamiaceae). Research Journal of Seed Science 1(1): 26-33.

[21] Mattana, E., Picciau, R., Puddu, S., Cuena Lombraña, A., Bacchetta, G. (2016): Effect of temperature and cold stratification on seed germination of the Mediterranean wild aromatic Clinopodium sandalioticum (Lamiaceae). - Plant Biosystems - An International Journal Dealing with all Aspects of Plant Biology 150(4): 846-850.

[22] Monostori, I., Arendas, T., Hoffman, B., Galiba, G., Gierczik, K., Szira, F., Vagujfalvi, A. (2016): Relationship between SPAD value and grain yield can be affected by cultivar, environment and soil nitrogen content in wheat. - Euphytica 211: 103-112.

[23] Özderin, S., Fakir, H., Dönmez, I. E. (2016): Chemical properties of Hawthorn Crataegus L spp Taxa Naturally Distributed in western Anatolia part of Turkey. - Sumarski List 7(8): 369-376.

[24] Panuccio, M. R., Fazio, A., Musarella, C. M., Mendoza-Fernández, A. J., Mota, J. F., Spampinato, G. (2018): Seed germination and antioxidant pattern in Lavandula multifida (Lamiaceae): A comparison between core and peripheral populations. - Plant Biosystems - An International Journal Dealing with all Aspects of Plant Biology 152(3): 398-406.

[25] Pedersen, L. H., Jorgensen, P. E., Pulsen, I. (1993): Effect of seed vigor and dormancy on field emergence, development and grain yield of winter wheat (Triticum aestivum L.) and winter barley (Horedeum vulgare L.). - Seed Science \&Technology 21(1): 159-178. 
[26] Rajkumar, J., Tiwari, P., Lal, S., Kumar, M., Singh, A., Kumar, A. (2017): Effect of boron and zinc application on nutrient uptake in guava (Psidium guajava L.) Pant Prabhat leaves. - International Journal of Current Microbiology and Applied Sciences 6(6): 19912002.

[27] Rather, A. A., Nawchoo, I. A., Ganaie, K. A., Shabir, P. A., Banday, A. (2016): Phenological attributes of Ajuga bracteosa: an unusual case from Kashmir Himalaya. Tropical Ecology 57(2): 369-373.

[28] Tariq, S. A., Bashharat, T., Khan, N., Rehman, Y. U. (2017): Elemental analysis of Indigofera gerardiana wall by atomic absorption spectrophotometer (AAS). - Advances in Basic Medical Science 1(1): 21-25.

[29] Turkoglu, S., Turkoglu, I., Kahyaoglu, M., Celık, S. (2010): Determination of antimicrobial and antioxidant activities of Turkish endemic Ajuga chamaepitys (L.) Schreber subsp. euphratica P. H. - Journal of Medicinal Plants Research 4(13): 12601268.

[30] Yaldiz, G. (2012): Some antimicrobial activity plants growing in Rize region used in alternative medicine. - Journal of Life Sciences 6: 624-631. 